\title{
Bercocok Tanam dalam Perspektif Hadis: Analisis Tekstual dan Kontekstual
}

\author{
Muhammad Ali \\ Program Studi Ilmu Hadis \\ Fakultas Ushuluddin dan Filsafat \\ UIN Alauddin Makassar \\ Email: alingampo05@gmail.com
}

\section{Abstrak:}

Farming is a typical way for human beings in order to provide food for survival in life and is frequently done in an area close to their settlement. To guarantee the availability of food for daily life, human beings farm a variety of plants not olny for their own needs, but also for generations to come. This writing is aimed at assessing and analyzing a farming-related hadith on both its sanad and matan. From sanad and matan perspective, the hadith is sound (sahih). Analyzing the hadith text and context, it is found that many lessons may be learnt, particularly the emphasis of the hadith on human effort to do farming in all seasons and occasions, since the harvest may be beneficial for them or for the others. The long term benefits of the farming is to ensure that the earth is and will always be a fertile ground for human beings to live, and to ensure the availability of food for all. From Islamic perspective, the benefits for others may act as the farmers' wordly philantrophic actions, and may lead to heavenly endless regards.

Kata Kunci: Hadis, Bercocok tanam, Teks, Konteks

\section{Pendahuluan}

Alam merupakan ciptaan Allah Swt. yang luar biasa terdapat banyak fenomena menakjubkan yang terkandung di dalamnya. Salah satu fenomena tersebut adalah fenomena tumbuh-tumbuhan (Flora). Tumbuh-tumbuhan merupakan 
salah satu makhluk hidup yang mendominasi ekosistem daratan. Kehidupan makhluk lain terutama manusia dan hewan sangat bergantung pada tumbuhan. Hal tersebut dikarenakan tumbuhan menempati posisi produsen dalam transformasi energi di alam. Proses fotosintesis hanya dapat dilakukan oleh tumbuhan dengan bantuan sinar matahari, yaitu mengubah karbondioksida (CO2) menjadi oksigen (02) untuk kemudian dilepaskan ke alam. Oksigen ini sangat diperlukan dalam proses respirasi bagi makhluk hidup yang membutuhkannya.

Peran tumbuh-tumbuhan terhadap manusia dan hewan tidak hanya sampai pada penyuplai oksigen, tetapi tumbuhtumbuhan juga sangat berperan terhadap kelangsungan dan kebutuhan hidup keduanya. Dalam menjaga kelangsungan hidup, hewan membutuhkan makanan sebagai sumber energi untuk bisa beraktivitas setiap hari. Untuk memenuhi kebutuhan akan makanan tersebut hewan membutuhkan tumbuhtumbuhan sebagai bahan konsumsi, begitupun dengan manusia. Manusia merupakan makhluk hidup yang mempunyai kebutuhan tinggi dalam menjaga kelangsungan hidup baik dari segi makan, minum, pakaian, tempat tinggal dan lain-lain, sebagian besar kebutuhan tersebut terdapat pada tumbuhtumbuhan. Tumbuh-tumbuhan merupakan makhluk hidup yang sangat dibutuhkan oleh manusia. Setiap hari manusia mengonsumsi nasi, sayur mayur, buah-buahan, pakaian yang dipakai setiap hari yang merupakan anggota dari kerajaan tumbuhan dan bahkan tumbuh-tumbuhan merupakan sumber devisa bagi suatu negara sebagai bahan industri.

Manusia dan tumbuh-tumbuhan merupakan dua hal yang tidak bisa dipisahkan. Keduanya memiliki keterikatan yang sangat erat dalam kehidupan di dunia dan merupakan mitra dalam menjaga kelangsungan hidup. Salah satu hal mendasar yang dibutuhkan oleh manusia dalam menjaga kelangsungan 
hidup yaitu dengan mengonsumsi makanan. Sebagian bahan makanan yang diperlukan oleh manusia berasal dari tumbuhtumbuhan.

Krisis pangan yang menyebabkan kelaparan dan bahkan menyebabkan kematian sangatlah memprihatinkan bagi manusia terutama ummat Islam. Padahal al-Qur'an jelas-jelas mengatakan dalam QS al-Isra'/17: 70.

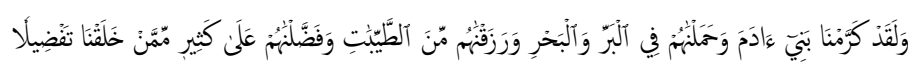

Terjemahnya:

Dan sungguh, Kami telah muliakan anak cucu Adam, dan Kami angkut mereka di darat dan di laut, dan Kami beri mereka rezeki dari yang baik-baik dan Kami lebihkan mereka di atas banyak makhluk yang Kami ciptakan dengan kelebihan yang sempurna.

Oleh karena itu untuk menghindari atau setidaknya dapat mengurangi krisis pangan tersebut maka manusia harus lebih memperhatikan bagaimana cara mendapatkan makanan. Salah satu solusi yang bisa dilakukan manusia adalah dengan bercocok tanam. Bercocok tanam merupakan salah satu langkah yang bisa diambil oleh manusia dalam mempertahankan kelangsungan hidup. Bukankah Allah swt. menjadikan tumbuhtumbuhan agar bisa dimanfaatkan oleh manusia terutama dalam memenuhi kebutuhannya. Sebagaimana firman Allah swt. dalam QS al-An'am/6: 99.

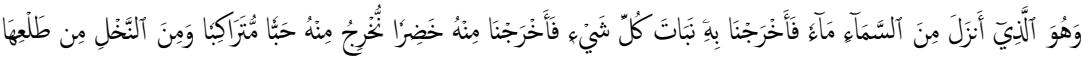

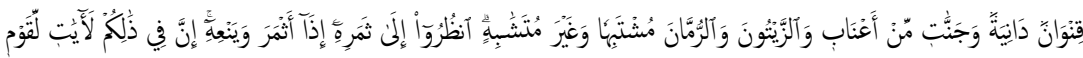

Terjemahnya:

Dan Dialah yang menurunkan air hujan dari langit, lalu Kami tumbuhkan dengan air itu segala macam tumbuhtumbuhan Maka Kami keluarkan dari tumbuh-tumbuhan itu tanaman yang menghijau. Kami keluarkan dari tanaman yang menghijau itu butir yang banyak; dan dari mayang korma 
mengurai tangkai-tangkai yang menjulai, dan kebun-kebun anggur, dan (kami keluarkan pula) zaitun dan delima yang serupa dan yang tidak serupa. perhatikanlah buahnya di waktu pohonnya berbuah dan (perhatikan pulalah) kematangannya. Sesungguhnya pada yang demikian itu ada tanda-tanda (kekuasaan Allah) bagi orang-orang yang beriman.

Dalam Islam sendiri bercocok tanam merupakan salah satu pekerjaan yang mulia. Ini dikarenakan bercocok tanam mempunyai banyak manfaat di antaranya, hasil dari bercocok tanam bukan hanya dirasakan oleh manusia tetapi juga oleh makhluk-makhluk lainnya. Ketika hasil tanaman tersebut dimakan oleh makhluk lain seperti burung dan sebagainya maka itu dianggap sebagai sedekah. Sebagaimana dalam hadis Rasulullah yang berbunyi:

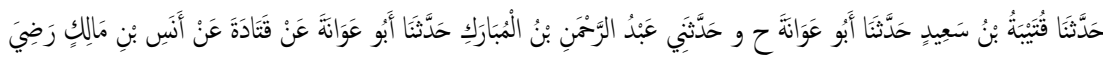

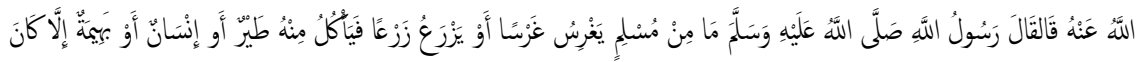

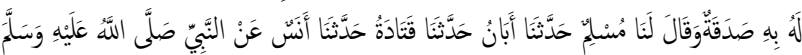

Artinya:

Telah menceritakan kepada kami Qutaibah bin Sa'ỉd telah menceritakan kepada kami Abū 'Awānah. Dan diriwayatkan pula telah menceritakan kepada saya 'Abdurrahman bin Al Mubārak telah menceritakan kepada kami Abū 'Awānah dari Qatādah dari Anas bin Mālik ra berkata; Rasulullah saw bersabda: "Tidaklah seorang muslim pun yang bercocok tanam atau menanam satu tanaman lalu tanaman itu dimakan oleh burung atau menusia atau hewan melainkan itu menjadi shadaqah baginya". Dan berkata, kepada kami Muslim telah menceritakan kepada saya Aban telah menceritakan kepada kami Qatadah telah menceritakan kepada kami Anas dari Nabi saw.

Karena banyaknya manfaat dari bercocok tanam, maka Rasulullah saw sendiri sangat menganjurkan kepada ummatnya untuk bercocok tanam. Sebagaimana sabdanya: 


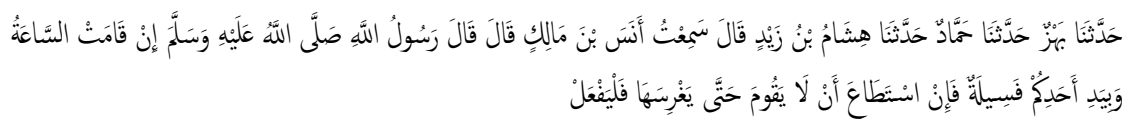

Artinya:

Telah bercerita kepada kami Bahz telah bercerita kepada kami Hammād telah bercerita kepada kami Hisyām bin Zaid berkata, saya mendengar Anas bin Malik berkata, Rasulullah saw bersabda: "Jika terjadi hari kiamat sedang salah seorang dari kalian mempunyai bibit kurma, jika mampu hendaklah jangan berdiri sampai dia menanamnya."

Begitu pentingnya kegiatan bercocok tanam sehingga Rasulullah memerintahkan ummatnya untuk menanam walaupun kiamat sudah berada di depan mata. Rasulullah tidak akan mungkin memerintahkan ummatnya untuk melakukan sesuatu kecuali terdapat kebaikan maupun manfaat di dalamya.

\section{Takhrij Hadis}

Hadis tentang keutamaan bercocok tanam telah ditemukan 9 jalur periwayatan, yaitu Musnad Ahmad bin Hanbal 2 jalur, Sunan Abū dawūd 1 jalur, Musnad Abdu bin Hamid I jalur, al-Adab al-Mufrad 1 jalur, Musnad al-Bazār 1, Mu'jam ibn al-Arabi 1 jalur, Musnad al-Maudu'I terdapat 2 jalur.

Adapun teks hadis yang akan dikaji oleh peneliti adalah:

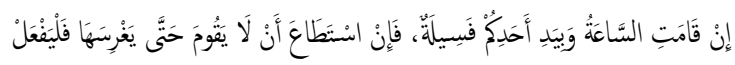

a. Metode Pertama Berdasarkan Lafal Awal Pada Matan Hadis.

Metode pertama Takhrīj al-ḥadis dengan menggunakan lafal pertama matan hadis dengan menggunakan kitab jāmi' alSagir karya Muhammad Nasiruddin al-Bāni. Adapun lafal awal matan hadis yang ditemukan dalam kitab tersebut degan yaitu:

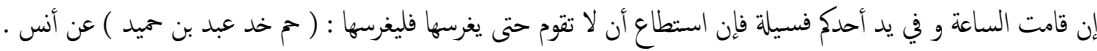

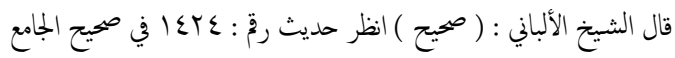

TAHDIS Volume 10 Nomor 1 Tahun 2019 
Hadis diatas diriwayatkan oleh Ahmad bin Hanbal ketika dalam pencarian menggunakan kata سطع maka peneliti juga menemukan potongan hadis sebagai berikut:

$$
\begin{aligned}
& \text { إن قامت الساعة وفي يد أحدى فسيلة فإن استطاع أن لا يقوم حتى يغرسها فليغرسها }
\end{aligned}
$$

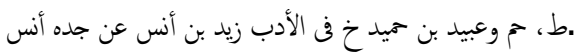

Hadis diatas diriwayatkan dalam kitab al-Tabrāni, Ahmad bin Hanbal pada sahabat 'Ubaid bin Humaid, kemudian dalam Kitab Bukhari pada bab al-Adab pada jalur Zaid bin Anas dari kakeknya Anas.

$$
\begin{aligned}
& \text { إن قامت الساعة وفي يد أحدك فسيلة فإن استطاع أن لا يقوم حتى يغرسها فليغرسها }
\end{aligned}
$$

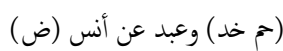

Hadis diatas diriwayatkan oleh Imam Bukhari dalam kitabnya pada bab al-Adab yang bersumber dari 'Abd dan Anas.

$$
\text { إن قامت الساعة وفي يد أحدك فسيلة فإن استطاع أن لا يقوم حتى يغرسها فليغرسها }
$$

$191:$ ז

Hadis diatas diriwayatkan oleh Imam Ahmad bin Hanbal pada juz 3 halaman 191.

$$
\begin{aligned}
& \text { إن قامت الساعة وفي يد أحدى فسيلة (فليغرسها) }
\end{aligned}
$$

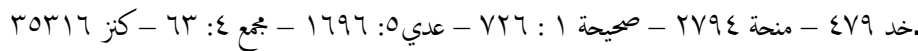

Selanjutnya hadis di atas terdapat dalam kitab Șahịh alBukhari pada bab al-Adab halaman 479, kemudian dalam kitab al-Minhahal-Ma'būdlial-Șāhati halaman 2794, kemudian dalam al-Silsilah Șahịh al-Albāni pada juz 1 halaman 726, selanjutnya dalam kitab al-Kāmilfial-Du'afā' liibn 'Ādi pada juz 5 halaman 1696, selanjutnya dalam Majmu' al-Zawā'idlial-Haisyami terdapat dalam juz 4 halaman 63, dan dalam kitab Kanzal'Ummāl pada halaman 35316.

b. Metode dengan salah satu lafal matan hadis

Metode dengan lafal pertama matan hadis dengan menggunakan dua kitab, yaitu al-Fath al-Kabīr fi Dimm alZiyādah ilā al-Jāmi' al-Ṣagīr dan Mawsū'ah Aṭrāf al-Ḥadīs alNabawi al-Asyarif . Dalam penelusuran kitab al-Fath al-Kabīr fi 
Ḍimm al-Ziyādah ilā al-Jāmi' al-Ṣagīr ditemukan hadis memiliki tema yang sama, namun pada awal matannya terdapat perbedaan.

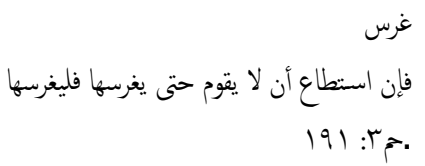

Potongan hadis diatas terdapat pada riwayat Imam Aḥmad bin Ḥanbal juz 3 halaman 191.

c. Metode dengan tema hadis

Metode ini berdasar pada pengenalan tema hadis. Kitab selanjutnya yang digunakan penulis adalah Kanzu al-'Ummāl karangan 'Alāiddin 'Ali al-Muttaqi ibn Ḥisām al-Dīn al-Hundi alBurhān Faūri, dan diperoleh sebagai berikut:

•إن قامت الساعة وفي يد أحدى فسيلة، فإن استطاع أن لا يقوم حتى يغرسها فليغرسها. "ح خد" وعبد بن حميد عن أنس -

Penjelasan kode diatas bahwa hadis terdapat pada Ahmad bin Hanbal, dan Imam Bukhāri.

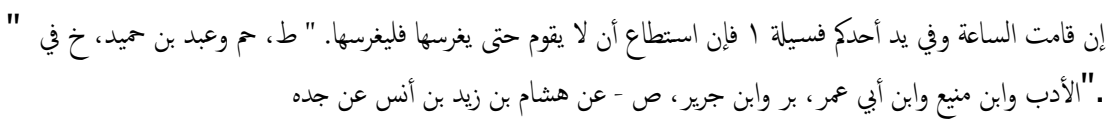

Penjelasan pada hadis ini bahwa hadis ini termuat dalam kitab al-Adab yang diriwayatkan dalam kitab al-Tabrani, Ahmad bin Ḥanbal, dan Imam Bukhāri.

Setelah melakukan pencarian pentunjuk melalui beberapa metode, maka peneliti menemukan beberapa petunjuk yang dapat mengarahkan ke berbagai kitab sumber. Namun, peneliti memulai pengumpulan hadis dengan melakukan pencarian pada kitab Sembilan Imam (al-Kutūb alTis'ah) dan setelah melakukan pencarian pada Kitab Sembilan peneliti melanjutkan pencarian diluar kitab Sembilan. Berdasarkan petunjuk tersebut peneliti menemukan sembilan jalur hadis hadis.

Dari Sembilan riwayat tersebut terdapat dalam kitab Musnad Aḥmad bin Ḥanbal, Sunan Abū Dāwūd, Musnad Abdu 
bin Hamid, kemudian dalam kitab al-Adab al-Mufrad, Musnad alBazār, Mu'jam ibn al-Arabi dan Musnad al-Maudu'I. Dan riwayat ini pada kitab al-Tis' ah hanya ditemukan di dalam kitab Musnad Aḥmad bin Hanbal dan Sunan Abū Dāwūd.

Adapun salah contoh teks teks hadis yang peneliti temukan di dalam al-Kutub al-Tis'ah, dan di luar Kutub al-Tis'ah antara lain :

Musnad Ahmad bin Hanbal

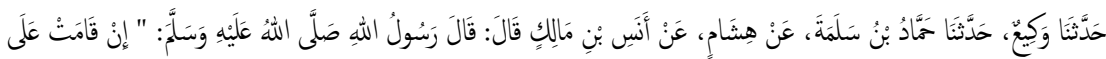

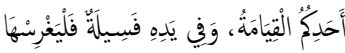

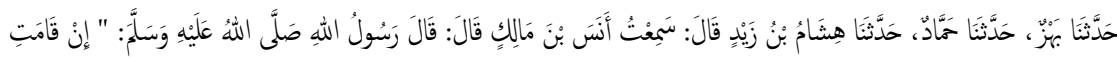

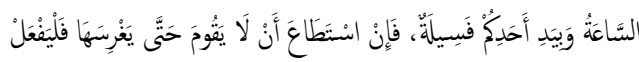

\section{Analisis Kualitas Hadis}

a. Dilihat dari segi sanad

Berikut hadis yang sanadnya akan diteliti oleh peneliti dalam kitab Ahmad bin Hanbal:

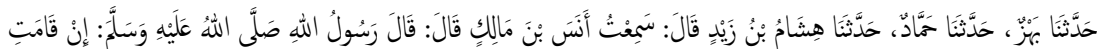

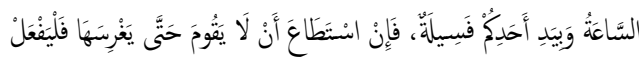

Dalam rangkaian sanad hadis di atas, terdapat beberapa periwayat yang yang akan dikaji untuk mendapatkan keșahihannya. Periwayat- periwayat tersebut adalah Ahmad bin Ḥanbal, Bahz, Hạmmād ibn Salamah, Hisyām ibn Zaid dan Anas ibn Mālik.

\section{Aḥmad bin Hanbal}

Beberapa gurunya dalam bidang hadis yaitu sufyan ibn Unayah, Yahya ibn Sa'id al-Qattan, dan Yazid ibn Harun ibn Wadi. Tentang diri beliau Ibnu Ma'in berkata"saya tidak melihat orang lebih baik (pengetahuannya di bidang hadis) melebihi Ahmad", sedangkan Asy Syafi'I berkata" saya keluar dari Baghdad dan di belakang saya tidak ada orang yang lebih paham tentang Islam, 
lebih zuhud, lebih wara', dan berilmu melebihi Ahmad. Beliau wafat pada tahun $241 \mathrm{H}$.

\section{Bahz}

Ketersambungan periwayatan antara Ahmad bin Hanbal dan Bahz dengan menggunakan Siqat Haddas̄āna dapat dibuktikan dengan beberapa alasan sebagai berikut:

Dilihat dari segi umur, Bahz wafat pada kisaran tahun 191-200 H, sedangkan Ahmad ibn Hanbal lahir pada tahun 164 dan wafat tahun $241 \mathrm{H}$ dalam usia 77 tahun. Ahmad bin Hanbal mulai meriwayatkan hadis pada umur 16 tahun yaitu bertepatan pada tahun 179. Kemungkinan bertemu antara Ahmad bin Hanbal sebagi murid dengan Bahz sebagai guru sangatlah besar karena Bahz wafat pada kisaran tahun 191-200an sedangkan Ahmad bin Hanbal sudah meriwayatkan hadis pada tahun 179.

Walaupun dalam riwayat hidup Ahmad bin Hanbal peneliti tidak menemukan nama Bahz terdapat dalam daftar guru tetapi dalam riwayat Bahz ditemukan bahwa Ahmad bin Hanbal merupakan salah satu muridnya.

Ahmad bin Hanbal sebagi pernah tinggal di Bashrah untuk mencari ilmu sedangkan Bahz juga pernah tinggal di Bashrah. Hal ini memungkinkan bagi keduanya yaitu Ahmad bin Hanbal sebagai murid dan Bahz sebagai guru untuk saling bertemu. Peneliti menilai bahwa keduanya adalah rawi yang adil dan dhābit (siqah) dengan melihat ungkapan kesepakatan para ulama kritikus hadis yang menggunakan siqah.

3. Hammād ibn Salamah

Untuk menilai ketersambungan sanad antara Bahz dan Hammad bin Salamah dengan menggunakan Siqat Haddas̄āna dapat dibuktikan dengan beberapa alasan sebagai berikut:

Hammad bin Salamah sebagai guru di dalam daftar riwayat murid-muridnya tidak mencantumkan nama Bahz. 
tetapi dalam daftar riwayat guru Bahz, Hammad bin Salamah merupakan salah satu guru Bahz.

Bahz sebagai murid pernah berdomisili di Bashrah begitupun dengan Hammad bin Salamah, hal ini memungkinkan adanya pertemuan diantara mereka dalam menerima dan memberi hadis.

Hammad bin Salamah sebagai guru lahir pada tahun 91 dan wafat tahun $167 \mathrm{H}$ dengan usia 76 tahun. Sedangkan Bahz wafat pada kisaran tahun 191-200 H. di lihat dari tahun lahir Hammad bin Salamah dengan tahun wafat Bahz sangatlah memungkinkan bahwa antara guru dan murid ini untuk saling bertemu.

\section{Hisyām ibn Zaid}

Abū Hāàtim al-Rāzì menilai Hisyām ibn Zaid sebagai orang Şalih. Untuk menilai ketersambungan sanad antara Hammād bin Salamah dan Hisyām ibn Zaid dengan menggunakan Siqat Haddas̄āna dapat dibuktikan dengan beberapa alasan sebagai berikut:

Dalam daftar riwayat hidup Hammād bin Salamah peneliti telah menemukan bahwa Hisyām ibn Zaid merupakan salah satu guru beliau. Begitupun di dalam daftar riwayat Hisyām ibn Zaid telah ditemukan Hammad bin Salamah sebagai murid beliau.

Hisyām ibn Zaid sebagai guru merupakan penduduk Bashrah selama hidupnya. Dan Hammād bin Salamah pernah berkunjung ke Bashrah dalam hal menimba ilmu. Hal ini dapat memungkinkan antara guru dan murid ini untuk saling bertemu.

5. Anas bin Mālik

Abū Hurairah berkata, "saya tidak melihat seorang yang salatnya lebih menyerupai Rasulullah saw. dibanding putra Ummu Sulaim, yakni Anas bin Malik. "setelah hidup cukup lama, mulai dari mengabdikan dirinya sebagai pelayan Nabi saw. Adapun daftar guru-guru Anas bin Malik adalah Mu'āz bin Jabal, 
Mahmūd bin al-Rabì', Abī Zar, 'Abdillah bin Mas'ūd, Abī Mūsā alAsyāri' .Sedangkan murid-muridnya yaitu Ahmad Hisyam bin Sa'id, Ahmad bin Saya'id. Anas bin Malik adalah sahabat Nabi yang meninggal paling akhir. Mengenai kapan Anas bin Malik wafat para ulama berbeda pendapat, ada yang mengatakan bahwa beliau wafat pada tahun $91 \mathrm{H}$, ada yang mengatakan 92 $\mathrm{H}$ dan ada juga yang mengatakan bahwa beliau wafat pada tahun $93 \mathrm{H}$. Adanya ketersambungan sanad antara Anas ibn Mālik dan Hisyām ibn Zaid dapat dilihat dari segi adanya hubungan darah dimana proses transmisi keilmuan Hisyām ibn Zaid khususnya dalam perjalanan periwayatan hadis dilakukan langsung kepada kakeknya Anas ibn Mālik.

b. Dilihat dari segi kualitas Matan.

Setelah mengidentifikasi jalur sanad periwayatan maka selanjutnya adalah klarifikasi matan hadis dengan dua kriteria utama yaitu terhindar dari syāż dan 'illah.

Setelah melakukan perbandingan antara matan satu dengan matan yang lain dari sembilan riwayat di atas, peneliti mendapat beberapa perbedaan. Namun dengan adanya perbedaan ini sama sekali tidak merusak makna yang sesungguhnya, walaupun ada beberapa hadis yang berbeda lafal matannya. Adapun dari perbedaan secara umum yaitu berbedaan mengenai panjang dan pendek suatu riwayat serta tanda bacanya. Berikut peneliti menguraikan beberapa berbedaan antara matan yang satu dengan matan yang lain:

Lafal terdapat pada semua hadis kecuali pada hadis terdapat Musnad ahmad bin hambal, Mu'jam Ibnu arabi dan hadis pada musnad Al mudhu'i menggunakan kata إنْ قَامَث saja.

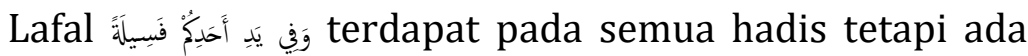
beberapa perbedaan di dalamnya yaitu: pada hadis Musnad

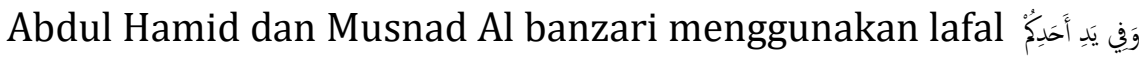


, فَسيَلَ pada hadis Musnad ahmad bin Hamal dan MusnadAl

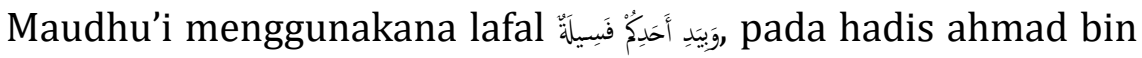
Hambal, Mu'jam ibnu arabi dan Musnad al Maudhu'i menggunakan lafal وَفَف يَدِهِ فَسِيلة pada hadis Musnad Abu Dawud

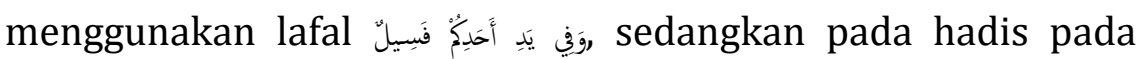

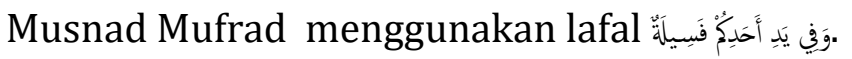

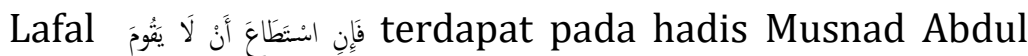
Hamid, musnad Ahmad bin hambal dan Musnad al Maudhu'i, pada hadis Musnad al Banzari dal Musnad Mufrad terdapat lafal tersebut tetapi ada perbedaan di akhir kata yaitu menggunakan kalimat sedangkan pada hadis Musnad Ahmad Bin Hambal, Musnad alBanzari, Mu'jam Ibnu Arabi, dan Musnad al Maudh'i

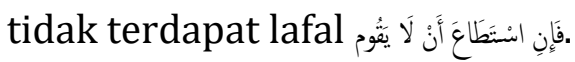

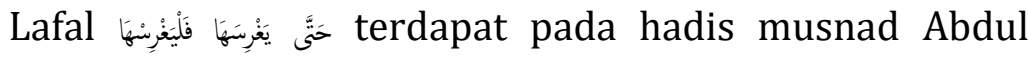
Hamid dan musnad Mufrad, pada hadis Musnad Ahmad Bin Hambal, Musnad Abu Dawud dan Musnad al Maudhu'i terdapat

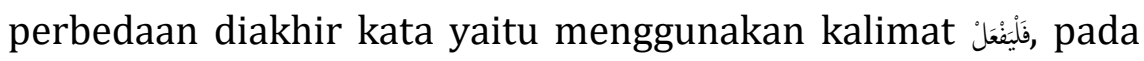

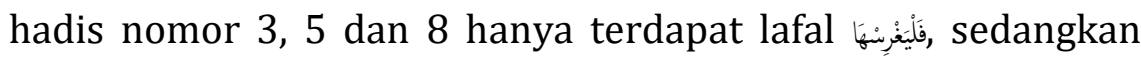

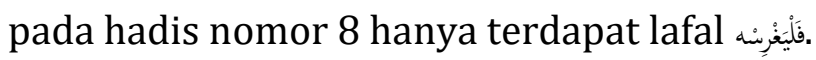

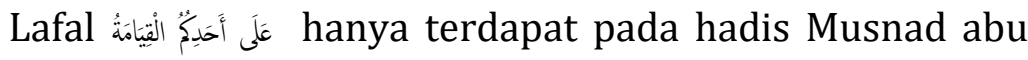
dawud dan Musnad Al Maudhu'i, dan terdapat pula dalam hadis Mu'jam arabi tetapi terdapat perbedaan diakhir lafal yaitu menggunakan kalimat السَّاعة.

Setelah melakukan perbandingan antara antara satu matan dengan matan yang lain, peneliti menyimpulkan bahwa hadis tersebut menggunakan riwāyah bi al-ma'na karena memiliki beberapa perbedaan lafal pada matannya namun sama maknanya. Untuk membuktikan apakah matan hadis tersebut tehindar dari 'illat atau tidak, maka dibutuhkan langkah-langkah yang dalam hal ini dikenal dengan kaidah minor matan, terhindar dari 'illat yaitu sebagai berikut : 
Tidak ada ziyādah. Ziyadah adalah tambahan dari perkataan perawi siqah yang biasanya terletak di akhir matan. Tambahan itu berpengaruh terhadap kualitas matan jika dapat merusak makna matan.

Tidak ada idrāj. Idrāj adalah adanya sisipan dalam matan hadis yang biasanya terdapat dipertengahan matan hadis, baik itu perkataan perawi atau hadis lain, yang bersambung dengan matan hadis tanpa ada keterangan sehingga tidak dapat dipisahkan. Tambahan seperti itu dapat merusak kualitas matan hadis. Tidak terjadi inqilāb. Inqilāb adalah terjadinya pemutar balikan lafal matan seperti mengakhirkan lafal yang seharusnya diawal.

Tidak terjadi taṣhif dan taḥrif, yakni perubahan yang terjadi pada titik huruf atau syakal huruf pada matan hadis.

Tidak terjadi tagyir, yakni perubahan (mengganti) satu atau lebih lafal matan yang asli dengan lafal lain. Dalam hadis tersebut terjadi tagyir sebagaiamana yang telah dijelaskan di atas, namun perubahan tersebut tidak terjadi pada matan.

Setelah melakukan kritik terhadap sanad dan matan hadis yang telah dijadikan sebagai objek kajian, maka dapat disimpulkan bahwa hadis yang diriwayatkan oleh imam Ahmad bin Hanbal berstatus sahih dengan alasan sebagai berikut:

Hadis tersebut memiliki pendukung yang berstatus syāhid dan mutābi', karena pada level sahabat ada satu orang yang meriwayatkan yaitu Anas bin Mālik dan Mutābi yaitu Hisyām ibn Zaid.

Berdasarkan analisis peneliti tentang sanad di atas, maka peneliti menyimpulkan bahwa hadis yang menjadi objek kajian telah memenuhi syarat keșahỉhan Sanad hadis, karena telah terpenuhi tiga unsur keșahỉhan sanad, yakni sanadnya bersambung serta rawinya adil dan dābit berdasarkan referensi atau dokumen-dokumen terpercaya yang penulis temukan. 
Adapun kualitas hadis yang menjadi obyek naqd al-ḥadis dinilai șahỉ karena memenuhi unsur keșahỉhan hadis. Hadis yang dikaji oleh penulis tidak menemukan kelemahan baik itu kelemahan yang terjadi pada sanad maupun pada matan hadis itu sendiri, sehingga ittiṣāl al-sanad terjadi.

\section{Analisis Kandungan Hadis Keutamaan Bercocok Tanam}

Sebagaimana hadis yang menjadi objek kajian dalam skripsi ini dan hadis yang telah di takhrijj adalah hadis riwayat Ahmmad bin Ḥanbal yaitu:

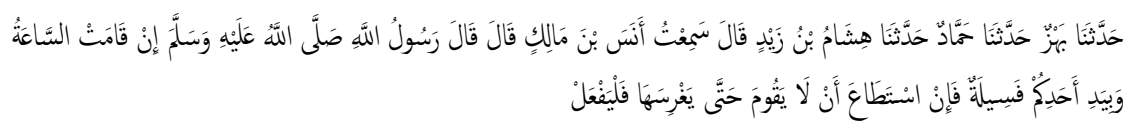

Artinya:

Telah bercerita kepada kami Bahz telah bercerita kepada kami Hammād telah bercerita kepada kami Hisyām bin Zaid berkata, saya mendengar Anas bin Malik berkata, Rasulullah saw bersabda: "Jika terjadi hari kiamat sedang salah seorang dari kalian mempunyai bibit kurma, jika mampu hendaklah jangan berdiri sampai dia menanamnya."

a. Tinjauan Tekstual Hadis tentang Keutamaan Bercocok Tanam

Pemahaman hadis secara tekstual disebut juga dengan interpretasi tekstual yaitu suatu pemahaman hadis berdasarkan teksnya semata, baik yang diriwayatkan secara lafal maupun yang diriwayatkan secara makna dan atau memperhatikan cakupan makna. Tekhnik interpretasi tekstual cenderung mengabaikan pertimbngan latar belakang peristiwa (wurūd) hadis dan dalil-dalil lainnya. Dengan demikian, tekstual hadis tentang keutamaan bercocok tanam dapat dilakukan dari dua aspek yaitu aspek mufradāt atau kosa kata yang terdapat dalam 
hadis yang menjadi objek kajian dan kandungan hadis secara utuh tanpa mengaitkan dengan kandungan hadis yang lain.

b. Syarah Mufradāt

قام-يقوم-قيام قَمَتِّ yang berarti berdiri, kata itu bisa juga berarti memelihara sesuatu agar tetap ada.

Dalam bahasa Arab, kata sā'ah secara umum berarti 'jam', 'waktu' atau ' jangka waktu tertentu'. Dalam al-Qur'an kata sā'ah terulang sebanyak 48 kali. Delapan diantaranya di dalam bentuk nakirah (ساءة: tanpa kata sandang al-) termasuk satu kali sebagai mudhāf pada kata majemuk (idhāfah) dan empat puluh kali dalam bentuk ma'rifah (اساعة).

Kata tersebut dapat menunjukkan periode waktu tertentu, atau bagian dari waktu- dapat lebih kecil dari satuan hari, jam, menit atau bahkan detik- yang selalu dinyatakan dalam bentuk nakirah (indefinitif, yakni: ساعة). Kata sā'ah yang menunjukkan pengertian demikian, antara lain seperti dalam QS Yūnus/10: 45.

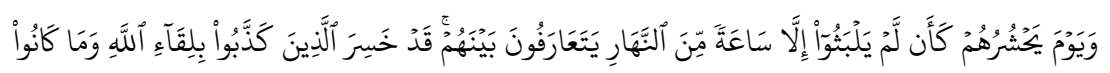

Terjemahnya:

Dan (ingatlah) akan hari (yang di waktu itu) Allah mengumpulkan mereka, (mereka merasa di hari itu) seakan-akan mereka tidak pernah berdiam (di dunia) hanya sesaat di siang hari, (di waktu itu) mereka saling berkenalan. Sesungguhnya rugilah orang-orang yang mendustakan Pertemuan mereka dengan Allah dan mereka tidak mendapat petunjuk.

Selain itu juga kata sā'ah mempunyai makna khusus yang berarti hari kiamat atau saat terjadinya kehidupan akhirat yang 
menggantikan kehidupan dunia. Untuk pengertian ini di dalam al-Qur'an selalu dinyatakan dalam bentuk ma'rifah (definitif) seperti firman Allah dalam QS al-A'rāf/7: 187.

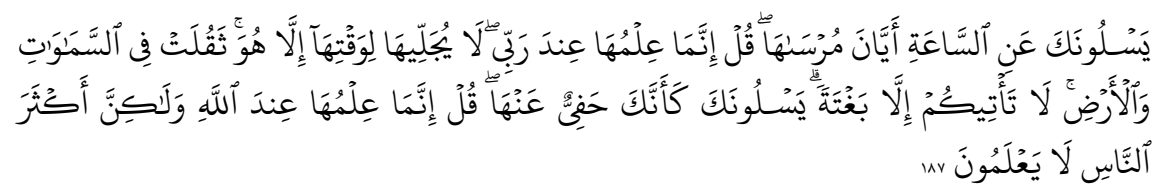

Terjemahnya:

Mereka menanyakan kepadamu tentang kiamat: "Bilakah terjadinya?" Katakanlah: "Sesungguhnya pengetahuan tentang kiamat itu adalah pada sisi Tuhanku; tidak seorangpun yang dapat menjelaskan waktu kedatangannya selain Dia. kiamat itu Amat berat (huru haranya bagi makhluk) yang di langit dan di bumi. kiamat itu tidak akan datang kepadamu melainkan dengan tibatiba". mereka bertanya kepadamu seakan-akan kamu benar-benar mengetahuinya. Katakanlah: "Sesungguhnya pengetahuan tentang bari kiamat itu adalah di sisi Allah, tetapi kebanyakan manusia tidak Mengetahui".

Hari kiamat dinyatakan dengan kata sā'ah, menurut beberapa mufassir yaitu untuk mengambarkan betapa cepat proses perhitungan amal dan perjalanan waktu pada hari tersebut, yang hanya berlangsung dalam sekejap. Sebagian ulama membedakan as-sā'ah dalam pengertian hari kiamat itu menjadi tiga macam, sebagaimana yang telah dikemukakan oleh Al-Ashafani, yakni: as-Sā'ah al-Kubrā (kiamat besar), as-Sā'ah alWusthā ( kiamat sedang), dan as-Sā'ah al-Shughrā (kiamat kecil). Kiamat besar adalah berakhirnya seluruh kehidupan dunia, yang dilanjutkan masa dibangkitkannya seluruh manusia untuk dimintai pertanggungjawaban atas segala perbuatannya selama hidup di dunia.

Adapun kiamat sedang adalah masa habisnya kehidupan suatu generasi, seperti berakhirnya generasi sahabat dengan tidak adanya seorangpun sahabat yang masih hidup. Yang 
dimaksud dengan sahabat menurut Al-Asqalani adalah orang yang pernah bertemu dengan Nabi dan beriman serta meninggal dalam keadaan beragama Islam.

Kiamat kecil adalah berakhirnya kehidupan atau datangnya kematian orang perorang diantara individu-individu masyarakat, dengan artian kematian merupakan kematian bagi seoraang. Selain pembagian diatas sebagian ulama hanya membagi ke dalam dua yaitu tanpa memasukkan kiamat sedang. Bagi yang berpendapat demikian dan membagi kiamat itu menjadi dua macam saja maka keadaan sebagaimana tersebut di dalam kiamat sedang itu dimasukkan sbagai keadaan pada kiamat kecil karena kehancuran alam secara menyeluruh belum terjadi.

Berasal dari kata يد yang semula kata ini berbunyi yadi (يدى) bentuk mutsannā-nya yadān (يدان) dan jamaknya al-aydi (أيدى). Dalam bahasa Arab, kata ini tergolong ism mu'annats. Secara harafiah, kata yad (يد) berarti tangan, telapak tangan, atau semua bagian tangan dari ujung jari hingga bahu. Dalam penggunaan sehari-hari, kata yad tidak saja dimaksudkan untuk makna haqiiqi tetapi juga dipergunakan untuk makna majāzi atau kiasan.

Dalam bahasa Arab dikenal seperti kata yad baidhä' (يديضي: secara harafiah artinya tangan putih), maksudnya 'pintar' atau 'jasa', yadan biyadin (يدابيد: tangan dengan tangan( berarti dengan bertatap muka atau kontan, dan beberapa pengertian lain dari yad yaitu: kekuasaan, kekuatan, kebaikan, kedermawanan, perlindungan, jaminan, dan sebaginya bergantung pada konteksnya dalam kalimat. Dalam al-Qur'an banyak sekali disebutkan kata yad baik dalam bentuk tunggal, mutsannā, maupun jamak, yang keseluruhannya mencapai 120 bilangan. 
Sebagian ahli menyatakan bahwa dari kata yad terdapat kata kerja jadian ayyada (ئيّ).

Kata tersebut dijumpai dalam al-Qur'an baik dalam bentuk kata kerja masa lampau ayyada maupun kata kerja kekinian yu'ayyidu. Kata-kata tersebut terdapat dalam QS Ali Imrān/3: 13, QS al-Baqarah/2: 87, 253; al-Maidah/5: 110. Masing-masing dari ayat tersebut berarti dukungan, batuan dan pertolongan untuk menambah dan menopang kekuatan yang sudah ada.

Merupakan isim masdar artinya bibit kurma atau anak pohon kurma yang diambil dari induknya.

Kata istathā'a ( sanggup, mampu) dan kata yang seakar dengannya disebut dalam Al-qur'an sebanyak 42 kali tersebar dalam 22 surah. Di dalam jumlahnya yang cukup banyak itu, kata tersebut hanya ditemukan di dalam bentuk kata kerjanya, baik dalam bentuk kata kerja lampau maupun bentuk kata kerja sekarang/akan datang. Tak satupun kata tersebut tertulis dalam bentuk mashdar, istathā'ah (انََّّاعَ: kesanggupan, kemampuan). Hal ini mengisyaratkan bahwa kemampuan selalu terkait dengan ruang dan waktu. Ada kalanya di dalam satu tempat dan waktu seseorang atau sesuatu memiliki kemampuan, tetapi pada kesempatan lain, kemampuan yang sama itu tidak dimilikinya.

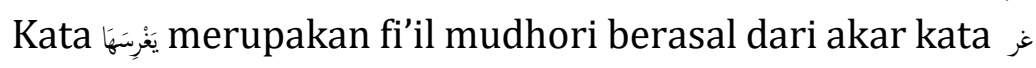
wyang artinya menanam.

Berasal dari kata فع yang artinya melakukan.

pemahaman terhadap matan hadis dengan memperhatikan sistematika matan hadis yang bersangkutan, 
atau hadis lain (tanawwu') dan/atau ayat-ayat al-Qur'an yang terkait.

Alam semesta ini diciptakan oleh Allah swt. sangat sempurna. Untuk mengatur kelangsungan hidup makhluk-Nya di bumi, Allah swt. telah memberikan kepercayaan kepada manusia untuk memakmurkan dan mengelolahnya dengan baik sehingga tidak terjadi bencana di bumi. Hal ini sesuai dengan firman-Nya dalam QS. Hud/11: 61.

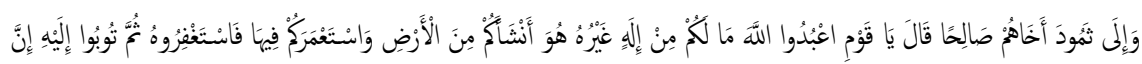

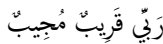

Terjemahnya:

Dan kepada Tsamud (kami utus) saudara mereka shaleh. Shaleh berkata: "Hai kaumku, sembahlah Allah, sekali-kali tidak ada bagimu Tuhan selain Dia. Dia telah menciptakan kamu dari bumi (tanah) dan menjadikan kamu pemakmurnya, karena itu mohonlah ampunan-Nya, kemudian bertobatlah kepada-Nya, Sesungguhnya Tuhanku amat dekat (rahmat-Nya) lagi memperkenankan (doa hamba-Nya)."

Kata (أنشآ ) ansya'akum/menciptakan kamu mengandung makna mewujudkan serta mendidik dan mengembangkan. Objek kata ini biasanya manusia dan binatang. Sedang kata (استعمر) ista'mara terambil dari kata (عمر) 'amara yang berarti memakmurkan. Kata tersebut juga dipahami sebagai antonim dari kata (خرب) yakni kehancuran. Huruf sin dan tā' yang menyertai kata ista'mara ada yang memahaminya dalam arti perintah sehingga kata tersebut berarti Allah memerintahkan kamu memakmurkan bumi dan ada juga yang memahaminya sebagai berfungsi penguat yakni menjadikan kamu benar-benar mampu memakmurkan dan membangun bumi. Ibnu Katsir memahaminya dalam arti menjadikan kamu pemakmurpemakmur dan pengelolah-pengelolahnya. 
Hadis tersebut menjelaskan bahwa tanah yang terlantar belum ada pemiliknya. Adapun pesan yang ingin disampaikan oleh Rasulullah terkait dengan hadis ini bahwa perlunya menggarap tanah sehingga membawa manfaat bagi kehidupan. Ayat maupun hadis diatas telah mengisyaratkan pentingnya memakmukan dan mengelolah bumi dan memanfaatkan lahan yang telah ada demi kemaslahatan manusia.

c. Tinjauan Kontekstual Hadis Keutamaan Bercoock Tanam

Pertama, Hadis tentang bercocok tanam yang telah mengisyaratkan pesan yang cukup mendalam agar seseorang memanfaatkan masa hidupnya untuk menanam sesuatu yang dapat dinikmati oleh orang-orang sesudahnya, sehingga pahalanya tetap mengalir sampai hari kiamat tiba. Hal ini akan ditulis sebagai amal sedekahnya (sedekah jariyah). Secara terminologi sedekah jariyah adalah pemberian atau derma yang mengalir secara terus pahalanya walaupun orang yang telah beramal itu meninggal dunia dengan dilakukan semata-mata ikhlas karena Allah. Rasullah saw. bersabda:

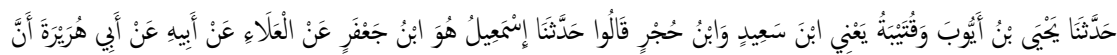

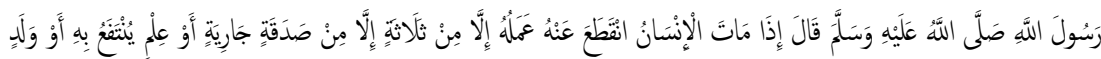

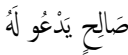

Artinya:

Telah menceritakan kepada kami Yahya bin Ayyub dan Qutaibah -yaitu Ibnu Sa'id- dan Ibnu Hujr mereka berkata; telah menceritakan kepada kami Isma'il -yaitu Ibnu Ja'fardari Al 'Ala' dari Ayahnya dari Abu Hurairah, bahwa Rasulullah shallallahu 'alaihi wasallam bersabda: "Apabila salah seorang manusia meninggal dunia, maka terputuslah segala amalannya kecuali tiga perkara; sedekah jariyah, ilmu yang bermanfa'at baginya dan anak shalih yang selalu mendoakannya." 
Bercocok tanam dianggap sebagai sedekah jariyah karena walaupun si penanam sudah meninggal dunia tetapi tumbuhtumbuhan yang ditanam tersebut masih dimanfaatkan oleh orang-orang maka amal si penanam akan terus mengalir karena apa yang telah ditanam bermanfaat bagi orang banyak. Hal ini sesuai dengan sabda Rasulullah:

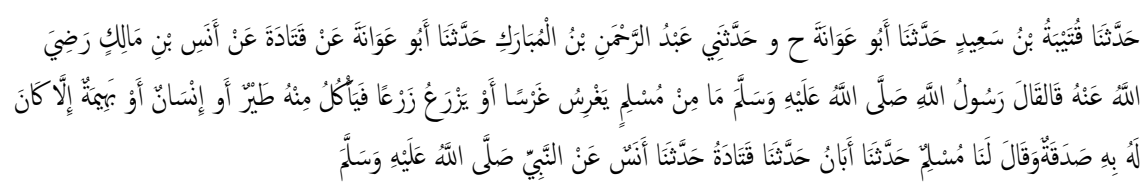

Artinya:

Telah menceritakan kepada kami Qutaibah bin Sa'ỉd telah menceritakan kepada kami Abū 'Awānah. Dan diriwayatkan pula telah menceritakan kepada saya 'Abdurrahman bin Al Mubārak telah menceritakan kepada kami Abū 'Awānah dari Qatādah dari Anas bin Mālik ra berkata; Rasulullah saw bersabda: "Tidaklah seorang muslim pun yang bercocok tanam atau menanam satu tanaman lalu tanaman itu dimakan oleh burung atau menusia atau hewan melainkan itu menjadi shadaqah baginya". Dan berkata, kepada kami Muslim telah menceritakan kepada saya Aban telah menceritakan kepada kami Qatadah telah menceritakan kepada kami Anas dari Nabi saw.

Kedua, hadis tersebut memberi petunjuk, bahwa sekiranya akan terjadi kiamat dan masih sempat menanam tanaman, maka nabi menyuruh agar taman tersebut segera ditanam. Ini menunjukkan betapa pentingnya kegiatan menanam pepohonan atau tumbuh-tumbuhan. Dalam hubungan ini menarik untuk dikemukakan komentar Muhammad Qutbh terhadap hadis ini, seperti yang dikutip Zainal Abidin Ahmad bahwa sangatlah mengesankan perintah menanam bibit kurma yang umurnya memakan waktu tahunan padahal kiamat sudah diambang pintu. Dikatakannya: ya Tuhan! Harus ditanamkannya? Dan apakah yang mesti ditanam itu? Bibit 
kurma yang baru menghasilkan buah setelah bertahun lamanya, padahal kehancuran dunia (kiamat) sudah pasti dengan yakin akan terjadi. Ya Allah! Hanya Nabi Islam, penutup dari segala, Nabi, yang akan berhak mengatakan ini. Islam satu-satunya agama yang mungkin menggerakkan hati manusia untuk berbuat ini, dan hanyalah Nabi satu-satunya yang mungkin membawa petunjuk demikian dan akan memimpin manusia lainnya. Inilah sejarah dunia seluruhnya.

Ketiga, Hadis tersebut memberikan gambaran atau petunjuk bahwa, begitu pentingya bekerja dalam kehidupan ini, sebagai salah satu sarana dalam mencari rezeki dan pekerjaan itu salah satunya adalah dengan bercocok tanam. Untuk memenuhi segala kebutuhan hidup, manusia diperintahkan oleh Allah untuk melakukan aktifitas atau bekerja. Berbagai pekerjaan dapat dilakukan oleh manusia dalam menjalankan misinya sebagai khalifa Allah di bumi. Allah swt. memberikan akal bagi manusia sebagai sarana untuk berfikir dalam memecahkan berbagai pesoalan hidup. Namun dalam memilih pekerjaan ada rambu-rambu yang harus diperhatikan oleh manusia yaitu bahwa pekerjaan itu adalah pekerjaan yang baik dan diridhai oleh Allah.

Bertani atau bercocok tanam merupakan salah satu dari mata pencaharian manusia yang turun temurun dilakukan. Karena sumber makanan manusia bersumber dari tanaman dan buah-buahan yang harus ditanam dan dibudidayakan serta dipelihara dengan penuh kesabaran dan ketelitian. Pekerjaan sebagai petani merupakan pekerjaan yang terpuji karena dalam bercocok tanam itu terdapat kemuliaan dan juga merupakan pekerjaan yang dilakukan dengan tangannya sendiri. Rasulullah bersabda:

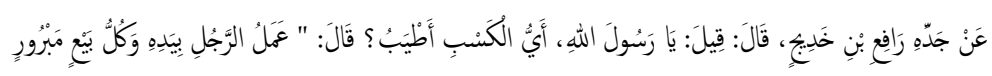

Artinya: 
Telah menceritakan kepada kami Yazid telah menceritakan kepada kami Al Mas'udi dari Wa`il Abu Bakr dari Abayah bin Rifa'ah bin Rafi' bin Khadij dari kakeknya Rafi' bin Khadij dia berkata, "Dikatakan, "Wahai Rasulullah, mata pencaharian apakah yang paling baik?" beliau bersabda: "Pekerjaan seorang laki-laki dengan tangannya sendiri dan setiap jual beli yang mabrur."

Setiap manusia memerlukan hasil pertanian yang merupakan hasil jerih payah para petani. Sehingga para petani itu sesungguhnya merupakan pejuang bagi kelangsungan hidup manusia. Para petani dengan penuh kesabaran dan tawakkal di bawah terik sinar panas matahari mengerjakan pekerjaannya tanpa keluh kesah.

Keempat, Meskipun kata yang digunakan dalam hadis ini adalah Fāsilatun yang berarti bibit pohon kurma yang diambil dari induknya. Bukan berarti tanaman selain tanaman yang telah disebutkan tidak dapat ditanam. Anggapan itu kurang bijaksana, sebab kata fāsilatun bukan dalam bentuk ma'rifah melainkan nakirah. Hal itu mengandung pengertian bahwa bukan hanya bibit pohon kurma yang yang diperintahkan untuk di tanam. Akan tetapi semua jenis tanaman yang dimiliki asalkan tanaman tersebut mengandung atau membawa keberkahan dan manfaat bagi kehidupan makhluk hidup. Syaikh Muhammad Nasruddin al-Bani berpendapat bahwa tidak ada sesuatu (yakni dalil) yang sangat kuat menunjukkan anjuran bercocok tanam sepeti dalam hadis yang mulia ini. Karena di dalamnya terdapat targhib (dorongan) besar untuk menggunakan kesempatan terakhir dari kehidupan seseorang dalam rangka menanam sesuatu yang telah dimanfaatkan oleh manusia setelah itu (si penanam) meninggal dunia. 


\section{Penutup}

Pemahaman Hadis tentang keutamaan bercocok tanam yang dijadikan sebagai objek tulisan baik ditinjau dari makna tekstualnya maupun kontekstualnya mengandung banyak arti atau makna-makna di dalamnya yaitu bahwa manusia harus selalu menanam tanaman di setiap ada kesempatan atau walaupun kesempatan tersebut terbatas karena hasil dari menanam tersebut dapat dimanfaatkan oleh orang-orang setelahnya dan akan bernilai sedekah bagi yang menanamya. Impikasinya yaitu bahwa bercocok tanam mempunyai beberapa manfaat yaitu manfaat yang bersifat dunia dalam artian sebagai upaya untuk memakmurkan bumi dan penyedia bahan makanan bagi manusia dan makhluk ciptaan Allah lainnya. Adapun manfaat yang bersifat agama yaitu sebagai sedekah dan perbuatan yang mendatangkan amal jariyah.

\section{DAFTAR PUSTAKA}

Al-Qur'ān al-Karīm.

al-Abnāsī, Ibrāhīm bin Mūsā. al-Syāżz al-Fiyaḥ min 'Ulūm Ibn alSalaḥ. Riyāḍ: Maktabah al-Rusyd, 1998 M.

Ahmad, Arifuddin. Metodologi Pemahaman Hadis: Kajian Ilmu Ma'āī al-Hadis. Cet. II; Makassar: Alauddin University Press, 2013.

al-Albani, Muhammad Nasaruddin. Sahih wa Da'if al-jami' alSagir. Juz 1. al-Maktaba al-Islamiyah, t, th.

al-Albani, Muhammad Nashiruddin. Silsilah Hadis Sahih. Jilid 1. Cet. I; Jakarta: Qisthi Press, 2005.

al-Bār, Abū Amr Yusuf ibn Abdullah ibn Muhammad Abd. alIsti'ab fi Ma'rifah al-Ashab. Juz 1. Cet. I; Bairūt: Dar alJail, 1992 M. 
Bariyah, Oneng Nurul. Materi Hadis tentang Islam, Ekonomi, Sosial dan Lingkungan. Cet. I; Jakarta: Kalam Mulia, 2008.

Departemen Pendidikan Nasional. Kamus Besar Bahasa Indonesia. Edisi IV. Cet. I; Jakarta: PT Gramedia, 2008.

Dewi, Diana Candra. Rahasia di balik Makanan Haram. Cet.I; Malang: UIN-Malang Press, 2007.

Faūri, Alāiddīn 'alì al-Muttaqīi ibn Ḥisām al-Dīn al-Hundì alBurhān. Kanzul 'Ummal. Juz 3. Bairūt: Muassasah alRisālah, 1989.

Faūri, Alāiddīn 'alì al-Muttaqīi ibn Ḥisām al-Dīn al-Hundì alBurhān. Kanzul 'Ummal. Juz 12. Bairūt: Muassasah alRisālah, 1989.

Gassing, Qadir. Etika Lingkungan dalam Islam. Cet. I; Makassar: Alauddin University Press, 2011.

al-Hasān, Ahmad bin Muhammad bin al-Husāin. al-Hidayah wal Irsyäd fi Ma'rifa. Juz 1. Cet. I; Bairūt: Dār al-Ma'rifa, 1407. Ibrāhīm, Ahmad bin 'Ali bin Muhammad. Rijal Shahih Muslim. Juz 1. Cet. I; Bairūt: Dār al-Ma'rifa, 1407.

al-'Irāqī, 'Abd al-Raḥīm bin al-Ḥusain. al-Taqyíd wa al-Ị̇aḥ Syarh Muqaddamah Ibn al-Ṣalah. Cet. I; Beirut: Dār al-Fikr, 1970.

al-Ju'fi, al-Imam Abi Abdillah Muhammad bin Ismail bin Ibrahim Ibn Mughirah. al-Jämi'u al-Shahih, Juz III. Cet. I; Libunan: Dar Thauqu al-Najati, $1442 \mathrm{H}$.

al-Ju'fi, al-Imam Abi Abdillah Muhammad bin Ismail bin Ibrahim. al-Jämi'u al-Shahih. Juz III. Cet. I; Libunan: Dar̄ Thauqu al-Najati, $1442 \mathrm{H}$.

Jumantoro, Totok. Kamus Ilmu Hadis. Cet. II; Jakarta: PT Bumi Aksara, 2002.

Kementerian Agama RI. Al-Qur'an dan Terjemahnya. Cet. I; Bandung: Syamil, 2012. 
al-Lihyāāī, Yūsuf bin Hāsyīm bin 'Abid. al-Khabr al-Sंabit. t. dt. al-Malibāri, Ḥamzah bin 'Abdillah. Ziyādah al-Siqah fi Mușțalah al- Hadis. t. dt.

Menanam pohon adalah sedekah, Saturday September 18, 2010. beranda wahyu2. blogspot. co. id/2010/09 menanampohon- adalah- sedekah. html. Diakses tanggal 17 Oktober 2017

al-Muhammadi, 'Abd. al-Qadir bin Mușțafā. al-Syāż̇ wa alMunkar wa Ziyādah al-Siqah. Cet. I; Beirut: Dār al-Kutub al-'Ilmiyyah, $2005 \mathrm{M}$.

Munawwir. Kamus al-Munawwir: Arab-Indonesia. Surabaya: Pustaka Progresif, 1997.

Munir. Hadis-hadis tentang Tumbuh-tumbuhan: Klasifikasi dan Kegunaanya. Cet. I; Makassar: Alauddin Press, 2013.

Pitriana, Pipit dan Diah Rahmatia. Bioekspo: Menjelajah Alam dengan Biologi. Solo: PT Wangsa Jatra Lestari, 2008. al-Qusyāiry, Muslim ibn al-Hajjāj abū al-Husain. al-Musnad alȘhahī al-Mukhtașir . Juz 3 . Bairūt: Dār Ihyā al-Turāṣ, t.th. Rama, Bahaking dkk. Pengetahuan Lingkungan. Makassar: Alauddin Press, 2009.

Rossidy, Imron. Fenomena Flora dan Fauna dalam Persfektif alQur'an. Cet. I; Malang: UIN Malang Press, 2008.

al-Sakhāwī, Muḥammad bin 'Abd al-Raḥmān. al-Tauḍih al-Abhar

li Tażkirah Ibn al-Malaqqan fi 'Ilm al-Aśar. alSa'ūdiyyah: Maktabah Ușūl al-Salaf, 1418 H.

Shihab, Muhammad Quraish. Enskiklopedia Al-Qur'an: Kajian Kosakata. Jilid 3. Cet. I; Jakarta: Lentera Hati, 2007.

Silalahi, Jansen. Makanan Fungsional. Cet.V; Yogyakarta: Kanisius, 2010.

al-Suyūṭi, Jalāl al-Dīn̄ Muhammad. al-Jāmi' al-Sagīr. Juz 1. Cet. II; Bairūt: Dāral-Kutubal-'Almiyyah, 1425H/ 2004. 
al-Syabānī, Abū Abdillāh Ahmad bin Hanbal bin Hilal bin Asida. Musnad al-Imām Ahmad Hanbal. Juz XX. Cet. I; Bairūt: Muassatun al-Risālah, 1418 H/1994 M.

Zaghlul, Abu Hājar Muḥammad al-Sa'id ibn Basyuni. Mausūa'halAträfal-Hadisal-Nabawiyyah al-Syariff. Juz 2. Beirūt: Dāral-Kutubal-'Ilmiyah. 